Journal of Supramolecular Structure 7:481-487 (1977)

Molecular Aspects of Membrane Transport 511-517

\title{
Reconstitution of Neutral Amino Acid Transport From Partially Purified Membrane Components From Ehrlich Ascites Tumor Cells
}

\author{
Gary Cecchini, Gregory S. Payne, and Dale L. Oxender \\ Department of Biological Chemistry, Medical Science I, University of Michigan, \\ Ann Arbor, Michigan 48109
}

\begin{abstract}
Solubilized protein fractions have been obtained from plasma membranes of Ehrlich ascites cells either by extraction with $0.5 \%$ Triton X-100 or by extraction with $2 \%$ cholate. Partial purification of the solubilized protein fraction has been obtained by utilizing a combination of ammonium sulfate precipitation and column chromatography. Leucine-binding activity has been detected in the Triton X-100 solubilized membrane fraction. The leucine-binding activity was measured by equilibrium dialysis and was saturable with high levels of leucine or phenylalanine and is not strongly effected by alanine. These properties are similar to those previously identified as System L. In addition, the cholate extracted protein fraction was partially purified and reconstituted into liposomes. Sodium dependent uptake of alanine and leucine could be demonstrated in the reconstituted vesicles. Concentrative uptake was dependent upon a sodium gradient. A membrane potential produced by valinomycin mediated potassium diffusion in the presence of sodium also stimulated amino acid transport in reconstituted liposomes.
\end{abstract}

Key words: reconstitution, transport, Ehrlich cell, amino acid, liposome

The transport of neutral amino acids in animal tissues is carried out by several distinct transport systems. Early studies on the detailed interactions for transport in Ehrlich ascites cells among a large group of natural and synthetic amino acids showed that the affinities of the neutral amino acids clustered into 2 groups which were transported by the $A$ and the $\mathrm{L}$ transport systems (1). We recently demonstrated that the $\mathrm{A}$ and $\mathrm{L}$ transport systems are present in mammalian cells grown in tissue culture as well as Ehrlich ascite cells (2). System A (alanine-preferring) serves mainly for such amino acids as alanine, glycine, and serine while System L (leucine-preferring) shows a preference for the branched chain and aromatic amino acids.

Several groups of investigators have successfully examined transport in vesicles derived from plasma membranes of animal cells (3-6). There have also been several reports of the successful reconstitution of transport systems from several mammalian cell types $(7-10)$ as well as a thermophilic bacterium (11). 
In this report, we have used the 2 detergents Triton $\mathrm{X}-100$ and cholate to solubilize plasma membrane fractions from Ehrlich ascites cells. We found that the Triton extract retains leucine-binding activity with a specificity similar to that of the $\mathrm{L}$ system but this preparation was not as useful for reconstitution studies. We were able to use the cholate solubilized membrane preparations to reconstitute transport activity for alanine and leucine by incorporating partially purified extracts into soybean phospholipid liposomes. The cholate extract could be partially purified by ammonium sulfate precipitation and column chromatography.

\section{METHODS}

$\mathrm{L}-\left[{ }^{3} \mathrm{H}\right]$ leucine and L- $\left[{ }^{3} \mathrm{H}\right]$ alanine were purchased from New England Nuclear Corporation (Boston, Massachusetts), and $\left[{ }^{14} \mathrm{C}\right]-\alpha$-methylglucopyranoside from AmershamSearle. Triton X-100 was obtained from Research Products International, and sodium cholate from Calbiochem (La Jolla, California). Soybean phospholipid (L- $\alpha$-phosphatidylcholine, Type II-S) and Concanavalin A-Sepharose were obtained from Sigma Chemical Company (St. Louis, Missouri). Membrane filters were from Millipore Company and Biogel P-60 was from Biorad Corporation (Richmond, California).

\section{Preparation of Plasma Membrane Fraction}

A plasma membrane fraction enriched approximately 25 -fold based upon $\mathrm{Na}^{+}, \mathrm{K}^{+}$. ATPase activity was obtained from the Ehrlich ascites cells by a slight modification of procedures described by Im et al. (12).

\section{Triton-solubilized Leucine-binding Component of Plasma Membrane Vesicles}

Plasma membrane vesicles ( $25 \mathrm{mg}$ of protein) in $15 \mathrm{mM}$ sodium phosphate buffer, $\mathrm{pH} 7.4$, were incubated with $0.5 \%$ Triton $\mathrm{X}-100$ for $30 \mathrm{~min}$ at $4^{\circ} \mathrm{C}$. After centrifugation at $35,000 \times \mathrm{g}$ for $50 \mathrm{~min}$ the supernatant fluid was brought to $10 \%$ saturation by addition of solid ammonium sulfate at $4^{\circ} \mathrm{C}$. This suspension was then centrifuged at $30,000 \times \mathrm{g}$ for $20 \mathrm{~min}$. Following centrifugation a pellicle containing the majority of the protein was found in the centrifuge tube and this was carefully removed and resuspended in $2 \mathrm{ml}$ of $15 \mathrm{mM}$ sodium phosphate buffer, $\mathrm{pH}$ 7.4. The protein solution was then placed on a Biogel P-60 column $(1 \times 16 \mathrm{~cm})$ previously equilibrated with the sodium phosphate buffer and $0.1 \%$ Trition $X-100$.

The majority of the protein applied to the column eluted in 1 broad peak near the void volume of the column. This material was pooled and placed on a Concanavalin A-Sepharose 4B affinity column $(0.5 \times 7 \mathrm{~cm})$ equilibrated with $15 \mathrm{mM}$ sodium phosphate, $\mathrm{pH} 7.4,1 \mathrm{mM} \mathrm{CaCl} 2$ and $\mathrm{MgCl}_{2}$, and $0.1 \%$ Triton $\mathrm{X}-100$. About $5 \mathrm{mg}$ of protein was applied to the column. About $3 \mathrm{mg}$ of this protein was rapidly eluted from the column. The remaining protein was removed by addition of the same buffer with $0.1 \mathrm{M} \alpha$-methylmannopyranoside (Pfansthiel). The leucine-binding activity was contained in the fraction that did not bind to the Concanavalin A-Sepharose $4 \mathrm{~B}$ column. No binding activity for leucine was detected in the material eluted with $\alpha$-methylmannopyranoside.

\section{Equilibrium Dialysis for Measurement of Leucine-binding Activity}

Binding activity was measured by equilibrium dialysis at $4^{\circ} \mathrm{C}$ in $15 \mathrm{mM}$ sodium

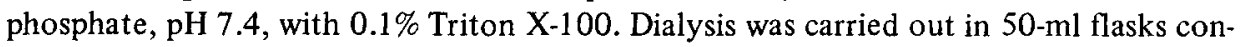
taining the above buffer with the addition of the appropriate labeled amino acid. Fractions 
containing from 1 to $5 \mathrm{mg}$ of protein in a final volume of $1 \mathrm{ml}$ of the same buffer were placed inside the dialysis bags. Dialysis proceeded with constant stirring of the solution until equilibrium had been reached $(12-24 \mathrm{~h}$ ). Triplicate samples were then removed from inside and outside the dialysis bag and the radioactivity was determined in a Packard scintillation counter. Sodium azide $(0.03 \%)$ was included in all dialysis solutions to prevent bacterial contamination.

\section{Reconstitution of Transport Activity From a Cholate Extract of Plasma Membrane Vesicle}

Extraction and purification. Ehrlich ascites plasma membrane vesicles ( $75 \mathrm{mg}$ in $8 \mathrm{ml}$ of $0.4 \mathrm{M}$ potassium phosphate buffer, $\mathrm{pH} 7.4$ ) were incubated with $2 \%$ sodium cholate, $1 \mathrm{mM}$ dithiothreitol, and $0.5 \mathrm{mM}$ EDTA for $30 \mathrm{~min}$ at $5^{\circ} \mathrm{C}$ with gentle mixing. The extract was then centrifuged at $100,000 \times \mathrm{g}$ for $60 \mathrm{~min}$. The clear supernatant fluid contained from 34 to $45 \mathrm{mg}$ of protein. The supernatant fraction was then brought to $20 \%$ saturation with solid ammonium sulfate $(114 \mathrm{~g} / \mathrm{liter})$ at $4^{\circ} \mathrm{C}$ and slowly mixed for $30 \mathrm{~min}$ before centrifugation at $35,000 \times \mathrm{g}$ in a Sorvall $\mathrm{RC} 2-\mathrm{B}$ centrifuge. The supernatant fraction containing $27-37 \mathrm{mg}$ of protein was dialyzed against $0.4 \mathrm{M}$ potassium phosphate (pH 7.4) containing $1 \%$ cholate, $1 \mathrm{mM}$ dithiothreitol for $12 \mathrm{~h}$. This material was then placed on a Biogel P-60 column $(1 \times 18 \mathrm{~cm})$ and eluted with the same buffer as used for dialysis. The majority of the protein $(21-27 \mathrm{mg}$ ) eluted as a large aggregate in the void volume of the column. This protein peak was then placed on a DEAE-cellulose column $(1 \times 22 \mathrm{~cm})$ and eluted with a linear gradient of $0.05 \mathrm{M}$ to $0.4 \mathrm{M}$ potassium phosphate buffer ( $\mathrm{pH}$ 7.4) containing $1 \%$ cholate and $1 \mathrm{mM}$ dithiothreitol. The initial fractions containing approximately $10 \mathrm{mg}$ of protein were pooled and used for reconstitution studies. The variation in different preparations resulted in a recovery of $15-30 \%$ of the protein initially extracted from the plasma membrane vesicles.

Reconstitution. The reconstitution of the protein fraction into artificial lipid vesicles was accomplished by a minor a modification of the cholate-dilution procedure of Racker (13). Crude soybean lecithin was partially purified according to the method described by Kagawa and Racker (14). The phospholipids were dispersed by sonication under $\mathrm{N}_{2}$ at $25-30^{\circ} \mathrm{C}$ in $2 \%$ cholate, $0.4 \mathrm{M}$ potassium phosphate $(\mathrm{pH} 7.4)$, and $1 \mathrm{mM}$ dithiothreitol until a clear suspension was obtained. The solubilized protein fraction described above was then added to the liposomes in a ratio of 20:1 (phospholipid to protein) and the mixture was dialyzed for $36 \mathrm{~h}$ at $4^{\circ} \mathrm{C}$ against $0.4 \mathrm{M}$ potassium phosphate buffer ( $\mathrm{pH} 7.4$ ) containing $1 \mathrm{mM}$ dithiothreitol. To determine if sealed liposomes were formed by this procedure an aliquot of the above was treated identically except $\left[{ }^{14} \mathrm{C}\right]-\alpha$-methylglucopyranoside was included. At the end of the dialysis the reconstituted liposomes with the $\left[{ }^{14} \mathrm{C}\right]-\alpha$-methylglucopyranoside were passed over a Biogel P-60 column $(1 \times 18 \mathrm{~cm})$ equilibrated with $0.4 \mathrm{M}$ potassium phosphate $(\mathrm{pH} \mathrm{7.4)}$. We found that $90 \%$ of the protein and a significant proportion of the labeled $\alpha$-methylglucopyranoside eluted in the void volume of the column indicating that the labeled sugar had been trapped by the reconstituted vesicles.

To measure uptake of radioactive amino acid the reconstituted vesicles $(0.8-1.2 \mathrm{mg}$ protein in $1 \mathrm{ml}$ ) containing high levels of potassium $(0.4 \mathrm{M})$ were resuspended in $9 \mathrm{ml}$ of $0.4 \mathrm{M}$ sodium phosphate ( $\mathrm{pH} 7.4)$ containing $0.1 \mathrm{mM}$ labeled amino acid $(2 \mu \mathrm{Ci} / \mathrm{ml})$. The liposomes were incubated at $37^{\circ} \mathrm{C}$ and in some cases $20 \mu \mathrm{g}$ of valinomycin in $10 \mu \mathrm{l}$ of $95 \%$ ethanol was added. At intervals $1-\mathrm{ml}$ samples were removed and filtered through membrane filters $(0.45 \mu \mathrm{m})$ and washed with $25-\mathrm{ml}$ portions of $0.4 \mathrm{M}$ potassium phosphate $(\mathrm{pH}$ 
TABLE I. Leucine Binding Activity Extracted With Triton X-100

\begin{tabular}{lc}
\hline Addition & $\begin{array}{c}\text { Ratio } \\
\text { cpm inside/cpm outside }\end{array}$ \\
\hline- & 1.65 \\
$100 \mu$ M Leucine & 1.01 \\
$50 \mu$ M Phenylalanine & 1.03 \\
$1 \mu$ M Alanine & 1.35 \\
\hline
\end{tabular}

Binding activity was measured by equilibrium dialysis as discussed in Methods. L- $\left[{ }^{3} \mathrm{H}\right]$ leucine at $10 \mathrm{nM}$ was included in all above dialysis experiments and cold amino acid at the concentration indicated in the table was added to each dialysis chamber.

7.4), $1 \mathrm{mM} \mathrm{CaCl}_{2}$ and $\mathrm{MgCl}_{2}$ at $4^{\circ} \mathrm{C}$. The filters were then rapidly removed, dried, and radioactivity was assayed in a Packard liquid scintillation counter. It required about 20 $25 \mathrm{sec}$ for filtering and washing the samples.

Protein in all cases was determined by the method of Lowry et al. (15).

\section{RESULTS AND DISCUSSION}

\section{Leucine-binding Activity Extracted From Plasma Membranes of Ehrlich Cells With Triton X-100}

Extraction of plasma membrane vesicles of Ehrlich cells with Triton X-100 as described in the Methods section usually solubilized $50-70 \%$ of the membrane proteins. Preliminary studies had already established that binding activity for leucine could be detected in the Triton X-100 extracts from the Ehrlich cell plasma membrane fraction (16). A further purification of the leucine-binding activity was accomplished by ammonium sulfate precipitation and Concanavalin A-Sepharose-affinity chromatography as described in the Methods section. These purification procedures yielded a protein fraction which upon analysis with sodium dodecyl sulfate-polyacrylamide gel electrophoresis showed from 4 to 7 Coomassie blue staining bands (data not shown). Utilizing various protein markers the bands have an apparent molecular weight range of 20,000-80,000 . The amount of Triton X-100 remaining bound to the protein in the preparation is unknown; thrrefore, the molecular weight values obtained should be viewed with appropriate caution. The binding activity does not involve a high affinity Concanavalin $\mathbf{A}$ receptor from the plasma membrane of Ehrlich cells because the material which bound tightly to the Concanavalin A-Sepharose column and had to be removed by elution with methyl $\alpha$-D-mannoside had no detectable leucine-binding activity. The binding activity for leucine was eluted from the Concanavalin A-Sepharose column in the early fractions which had little affinity for the lectin and were only slightly retarded.

The properties of the partially purified leucine-binding activity obtained from the Ehrlich cell plasma membrane are shown in Table I. A binding ratio of 1.65 was obtained during equilibrium dialysis with $10 \mu \mathrm{M}$ leucine. The addition of a 10,000-fold excess of unlabeled leucine decreases the ratio to 1.0 indicating that the binding activity was saturable. Phenylalanine is transported in intact Ehrlich cells by System $\mathrm{L}$ to about the same extent as leucine (1); therefore, phenylalanine would also be expected to inhibit leucine- 
binding activity. Table I shows that this was the case. Alanine also partially inhibits leucine-binding. Oxender and Christensen (1) reported that alanine, although mostly transported by System A, will compete to some extent with leucine for entry into Ehrlich cells. The binding activity for leucine described here has properties similar to those observed for leucine transport into intact Ehrlich cells.

Attempts to demonstrate binding activity for System $\mathrm{A}$ amino acids such as Lalanine and glycine were unsuccessful using the Triton X-100 solubilized plasma membrane fractions. Thus the binding activity seems to be present only for System $L$ amino acids and not System A. We were also not able to reconstitute leucine transport activity into lipid vesicles using this preparation. This failure may be related to the difficulty of removing the Triton X-100. Treatment of the preparation with Bio Beads SM-2 to remove the Triton X-100 resulted in a complete loss of detectable binding activity for leucine.

\section{Reconstitution of Neutral Amino Acid Transport Using Cholate Extracted Plasma Membrane Vesicles of Ehrlich Cells}

Cholate extraction of Ehrlich cell plasma membrane vesicles as described in the Methods section solubilized $40-60 \%$ of the membrane proteins. The extract was used to reconstitute phospholipid vesicles from either soybean phospholipid or a mixture of purified phospholipids composed of a 4:1 ratio of phosphatidylcholine to phosphatidylethanolamine. Analysis of the plasma membrane showed 50-60 Coomassie blue staining bands on sodium dodecyl sulfate slab gel electrophoresis. The reconstituted liposomes were used to demonstrate uptake of alanine or leucine which was dependent upon a gradient of sodium ions. Since Johnston and Bardin (7) had already shown that cholate extracts of Ehrlich cell plasma membrane vesicles could be used to form reconstituted liposomes that would concentrate System A amino acids such as $\alpha$-aminoisobutyric acid, it was of primary interest in this investigation to attempt to purify the components responsible for transport activity.

The Methods section describes the procedures utilized to obtain a partial purification of the components required for the transport of alanine and leucine. The protein fraction obtained by these procedures contains 10-15 Coomassie blue bands when subject to gel electrophoresis (data not shown). The molecular weight ranges of the proteins present in this fraction appear to be between 30,000 and 130,000 using standard proteins on the sodium dodecyl sulfate gels.

Table II shows the time course of the uptake of alanine and leucine by soybean phospholipid reconstituted with the partially purified extract. The uptake of alanine and leucine requires the addition of sodium to the medium. Maximum uptake occurs $3 \mathrm{~min}$ after the initiation of uptake and then appears to diminish. This loss of amino acid probably represents a decay in the sodium gradient. If sodium is not added to the reconstituted liposomes but is replaced by potassium, amino acid uptake does not take place (data not shown). Thus, sodium is required for the transport of both leucine and alanine by the reconstituted liposomes.

\section{Generation of Membrane Potential}

Lever has previously shown that membrane potential can be used to drive $\alpha$-aminoisobutyric acid uptake in membrane vesicles of $3 \mathrm{~T} 3$ cells $(6)$. We were able to demonstrate increased uptake for alanine in the reconstituted $\mathrm{K}^{+}$-loaded vesicles when valinomycin was added to the medium (Table III). The uptake of alanine was more rapid when valinomycin was included than that observed for sodium alone. The "overshoot" is also much more 
TABLE II. Uptake of Alanine and Leucine by Reconstituted Soybean Phospholipid Vesicles

\begin{tabular}{lcc}
\hline & \multicolumn{2}{c}{ Uptake } \\
Time (min) & $\begin{array}{c}\text { Alanine } \\
\text { nmoles/mg protein }\end{array}$ \\
\hline 1 & 0.05 & 0.07 \\
2 & 0.25 & 0.11 \\
3 & 0.42 & 0.23 \\
4 & 0.40 & 0.20 \\
7 & 0.21 & 0.18 \\
7 & 0.23 & 0.15 \\
\hline
\end{tabular}

Uptake of $0.1 \mathrm{mM} \mathrm{L-alanine} \mathrm{and} 0.05 \mathrm{mM}$ L-leucine by reconstituted soybean phospholipid vesicles. Each time point represents $100 \mu \mathrm{g}$ of reconstituted protein. Uptake was initiated by the addition of $0.4 \mathrm{M}$ sodium phosphate, $\mathrm{pH} 7.4$ to phospholipid vesicles prepared in potassium phosphate. $\mathrm{O}$ ther assay conditions are described in the Methods section.

TABLE III. Alanine Uptake in Reconstituted Soybean Phospholipid Vesicles

\begin{tabular}{|c|c|c|c|}
\hline \multirow[b]{3}{*}{ Time (min) } & \multicolumn{2}{|c|}{$37^{\circ} \mathrm{C}$} & $2^{\circ} \mathrm{C}$ \\
\hline & A. & B. & C. \\
\hline & \multicolumn{3}{|c|}{ nmoles/mg protein } \\
\hline 1 & 0.11 & 0.26 & 0.01 \\
\hline 2 & 0.33 & 0.43 & 0.05 \\
\hline 3 & 0.30 & 0.42 & 0.03 \\
\hline 4 & 0.28 & 0.23 & 0.09 \\
\hline 5 & 0.29 & - & 0.04 \\
\hline 7 & 0.26 & 0.23 & - \\
\hline
\end{tabular}

Uptake of $0.1 \mathrm{mM}$ L-alanine by reconstituted soybean phospholipid vesicles preloaded with $0.4 \mathrm{M}$ potassium phosphate, $\mathrm{pH} 7.4$.

A. $0.4 \mathrm{M}$ sodium phosphate, $\mathrm{pH} 7.4$ added with L-alanine to initiate uptake at $37^{\circ} \mathrm{C}$.

B. Same as A with the addition of $2 \mu \mathrm{g} / \mathrm{ml}$ of valinomycin added at time zero.

C. Same as B except uptake was measured at $2^{\circ} \mathrm{C}$.

pronounced and this may be due to a more rapid dissipation of the gradient of membrane potential when coupled to valinomycin-mediated potassium diffusion. Table III shows that transport at $37^{\circ} \mathrm{C}$ is severalfold higher than at $2^{\circ} \mathrm{C}$.

Accurate measurements of initial rates are rather difficult in the reconstituted system since considerable variation was obtained for the low transport rates observed. The sodium-dependent alanine uptake was saturable with alanine concentrations greater than $1 \mathrm{mM}$ (data not shown). Leucine uptake in this reconstituted system appears to be sodium dependent; however, it is difficult to show sodium-dependent uptake of leucine in whole cells (1) presumably because of the dominance of the sodium-independent System L. It may be that leucine uptake observed in this study is the result of entry by System A. These results are consistent with our failure to observe System $L$ leucine-binding activity in the cholate extracted material in contrast to the earlier studies with the Triton X-100 ex. tracted material. In addition, when transport was measured in liposomes that were reconstituted without protein added, active uptake was not observed. 
The present study confirms and extends the studies of Johnstone and Bardin (7) on the reconstitution of neutral amino acid transport from Ehrlich cells in liposomes. The purification of the transport components has been greatly facilitated by the ability to reconstitute transport into artificial lipid vesicles. We are currently attempting to further purify the membrane transport activity.

\section{ACKNOWLEDGMENTS}

This research was supported by the National Institutes of Health, grant GM 20737 for D. L. O.

\section{REFERENCES}

1. Oxender DL, Christensen HN: J Biol Chem 238:3686, 1963.

2. Oxender DL, Lee M, Moore PA, Cecchini G: J Biol Chem 252:2675, 1977.

3. Colombini M, Johnstone RM: J Membr Biol 15:261, 1974.

4. Hamilton RT, Nilsen-Hamilton M: Proc Natl Acad Sci USA 73:1907, 1976.

5. Quinlan DC, Hochstadt J: J Biol Chem 251:344, 1976.

6. Lever JE: J Cell Physiol 89:779, 1976.

7. Johnstone RM, Bardin C: J Cell Physiol 89:801, 1976.

8. Kasahara M, Hinkle PC: Proc Natl Acad Sci USA 73:396, 1976.

9. Shertzer HG, Racker E: J Biol Chem 251:2446, 1976.

10. Zala CA, Kahlenberg A: Biochem Biophys Res Commun 72:866, 1976.

11. Hirata H, Sone N, Yoshida M, Kagawa Y: Biochem Biophys Res Commun 69:665, 1976.

12. Im WB, Christensen HN, Sportés B: Biochim Biophys Acta 436:424, 1976.

13. Racker F: J Biol Chem 247:8198, 1972.

14. Kagawa Y, Racker E: J Biol Chem 246:5477, 1971.

15. Lowry OH, Rosebrough NJ, Farr AL, Randall RJ: J Biol Chem 193:265, 1951.

16. Cecchini G, Lee M, Oxender DL: J Supramol Struct 4:441, 1976. 